\title{
Dexamethasone Enhances the Effects of Parathyroid Hormone on Human Periodontal Ligament Cells In Vitro
}

\author{
R. M. Nohutcu, ${ }^{1,2}$ M. J. Somerman, ${ }^{1,3}$ L. K. McCauley ${ }^{1}$ \\ ${ }^{1}$ Department of Periodontics/Prevention/Geriatrics, The University of Michigan, 1011 N. University Ave., \\ Ann Arbor, Michigan 48109-1078, USA \\ ${ }^{2}$ University of Hacettepe, Faculty of Dentistry, Department of Periodontology, Ankara, Turkey \\ ${ }^{3}$ Department of Pharmacology, The University of Michigan, Ann Arbor, Michigan 48109, USA
}

Received: 19 October 1994 / Accepted: 27 December 1994

\begin{abstract}
Periodontal ligament cells (PDL) are thought to play a major role in promoting periodontal regeneration. Recent studies, focused on characterizing PDL cells, have been directed at establishing their osteoblast-like properties and determining biological mediators and/or factors that induce osteoblastic cell populations in the PDL. The glucocorticoid, dexamethasone (Dex), has been shown to selectively stimulate osteoprogenitor cell proliferation and to induce osteoblastic cell differentiation in many cell systems. In the present study the ability of Dex to modulate parathyroid hormone (PTH)-stimulated cAMP synthesis in cultured human PDL cells was examined. PDL cells, obtained from premolar teeth extracted for orthodontic reasons, were cultured with Dex (0-1000 $\mathrm{nM}$ ) for 7 days prior to PTH (1-34) stimulation. The exposure of PDL cells to Dex resulted in a dose-dependent increase in cAMP production in response to PTH stimulation. This response was seen in cells obtained from three different patients. The first significant Dex effect was seen on day 7 when compared to day 1 for $100 \mathrm{nM}$ Dex. PTH (1-34) stimulation caused a dose-dependent increase in cAMP synthesis after Dex $(1000 \mathrm{nM})$ treatment for 7 days. Conversely, stimulation of the cells with PTH (7-34) (0-1000 nM) did not increase cAMP production in PDL cells after Dex treatment. Forskolin- $(1 \mu \mathrm{M})$ and isoproterenol- $(1 \mu \mathrm{M})$ stimulated cAMP synthesis was not augmented by Dex treatment. Dex treatment did not alter calcitonin- $(1 \mu \mathrm{M})$ stimulated cAMP production in PDL cells. Glucocorticoid enhancement of PTH-stimulated cAMP synthesis in these cells supports the presence of an osteoblast-like population in the PDL, in vitro.
\end{abstract}

Key words: Periodontal ligament - Cyclic AMP - Dexamethasone - Parathyroid hormone - Osteoblast.

The ultimate goal for the treatment of periodontal disease is regeneration of mineralized and soft connective tissue components of the periodontal attachment apparatus lost by the inflammatory process. This requires regeneration of fibrous connective tissue, formation of new bone, and reattachment of new connective tissue fibers into newly formed cementum [1-3]. When appropriately triggered, periodontal ligament (PDL) cells are thought to play an important role in promot-

Correspondence to: L. K. McCauley ing periodontal regeneration and alveolar bone homeostasis. Recent studies designed to characterize PDL cells have been directed at establishing their osteoblast-like properties and determining biological mediators and/or factors that influence their regenerative capacity [4-9]. Cell functions that have been examined under various conditions include migration, attachment, proliferation, and ability of cells to form new bone, cementum, and connective tissue attachment in vivo and in vitro $[7,9,10]$.

It is known that the PDL contains a heterogeneous cell population with a subpopulation of cells having osteoblastic characteristics including high alkaline phosphatase levels, increased cAMP production in response to PTH stimulation, the capacity to form mineral-like nodules in vitro, and increased bone Gla protein production in response to $1,25(\mathrm{OH})_{2}$ vitamin $\mathrm{D}_{3}[4,11-13]$. Although some of the recent studies support the theory that PDL fibroblasts are precursor cells of osteogenic origin, it is still unclear whether mature PDL tissues contain osteogenic progenitor cells having the capacity, when appropriately stimulated, to differentiate. Characterization of PDL cells at the biochemical and molecular level is necessary to establish the exact role these cells play in periodontal health and regeneration and to improve the success of clinical procedures. Importantly, the PDL in a similar fashion to other ligaments in the body, has a role in the regulation of hard and soft connective tissue. Knowledge obtained as to the factors and/or mediators affecting osteoblastic differentiation of these cells may provide a better understanding of mechanisms controlling hard tissue-ligament interactions in general. Our laboratory has focused on further characterization of the osteoblast-like properties of PDL cells, specifically, the effects of glucocorticoids on PTH-mediated increased cAMP in these cells.

Glucocorticoids modulate the cellular effects of a variety of factors, including other hormones on cell function. Recent evidence suggests that glucocorticoids mediate the presence and function of cellular receptors for other hormones [14, 15]. Dexamethasone (Dex), a potent synthetic glucocorticoid, has been shown to selectively stimulate proliferation of osteoprogenitor cells and to induce rat and human bone marrow stromal cells to differentiate into osteoblasts [16-18]. Pretreatment of bone explants or bone cells with glucocorticoid in vitro enhances PTH-mediated cAMP production $[19,20]$. Although there are several reports on various effects of glucocorticoids on fibroblasts [21], there is a paucity of information regarding the effect of glucocorticoids on cAMP production in fibroblasts.

PTH-responsive adenylate cyclase activity has been as- 
sociated with the osteoblastic phenotype, and dexamethasone stimulates osteoblast differentiation. The purpose of this study was to evaluate the ability of Dex to stimulate a population of PTH-responsive cells within the PDL.

\section{Materials and Methods}

\section{Supplies}

Dulbecco's Modified Eagle Medium (DMEM) and fetal bovine serum (FBS) were purchased from Gibco BRL (Grand Island, NY) Dex, isoproterenol forskolin, and isobutylmethylxanthine (IBMX) were obtained from Sigma Chemical Co. (St. Louis, MO); BSA was purchased from Amresco (Solon, OH); PTH (1-34) and PTH (7-34) were obtained from Bachem California (Torrance CA).

\section{Cell Isolation and Culture}

PDL fibroblasts were cultured as reported in detail previously [11]. Briefly, fibroblasts were obtained from the periodontal ligaments of premolar teeth extracted for orthodontic reasons. After extraction, the teeth were placed in biopsy media (DMEM with $10 \%$ FBS, 250 $\mu \mathrm{g} / \mathrm{ml}$ gentamicin sulfate, $5 \mu \mathrm{g} / \mathrm{ml}$ amphotericin $\mathrm{B}, 100 \mathrm{U} / \mathrm{ml}$ penicillin, $100 \mu \mathrm{g} / \mathrm{ml}$ streptomycin). Only periodontal ligament attached to the middle third of the root was removed with a scaler to avoid contamination with gingival and apical tissue. The PDL tissues were cut into small pieces, rinsed with biopsy media, placed in tissue culture dishes, and glass coverslips were placed over the tissues to prevent floating. PDL tissues were incubated in biopsy medium in a humidified atmosphere of $95 \%$ air and $5 \% \mathrm{CO}_{2}$ at $37^{\circ} \mathrm{C}$ overnight. The following day, biopsy medium was replaced with culture medium (DMEM with $10 \%$ FBS, $100 \mathrm{U} / \mathrm{ml}$ penicillin, $100 \mu \mathrm{g} / \mathrm{ml}$ streptomycin). After reaching confluency, cells were passaged with $0.25 \%$ trypsin- $0.1 \%$ EDTA. PDL cells were used between the fourth and seventh passage for all experiments.

\section{Treatment of PDL Cells}

PDL cells were plated into 24 -well plates $(50,000$ cells/well) and grown to confluence before treatment with either vehicle or Dex. Unless otherwise indicated, PDL cells were treated with vehicle or Dex for 7 days with media replacement every 48 hours. Dexamethasone was selected for this study because it has been reported to be more potent than the many other steroids on glucocorticoidregulated functions of osteoblasts [20,22]. For cAMP assays, cells were treated with different concentrations of Dex $(0-1000 \mathrm{nM})$ prior to stimulation with PTH (1-34) for 10 minutes. For time course experiments, PDL cells were treated with Dex $(0-1000 \mathrm{nM})$ for $1,3,7$, and 14 days followed by PTH (1-34) (100 nM) stimulation for 10 minutes. To determine the specificity of the dexamethasone effect on PTH-stimulated cAMP levels, cells were treated with Dex (1000 $\mathrm{nM}$ ) for 7 days followed by a 10-minute stimulation with calcitonin $(1 \mu \mathrm{M})$, isoproterenol $(1 \mu \mathrm{M})$, forskolin $(1 \mu \mathrm{M})$, or PTH $(1-34)(100$ $\mathrm{nM})$. The cAMP data were standardized to cell number using parallel cultures enumerated by trypan blue dye exclusion and hemocytometer cell counting.

\section{Adenylate Cyclase Stimulation Assay}

Adenylate cyclase stimulation was evaluated as previously described by measuring cAMP production by periodontal ligament cells [6]. PDL fibroblasts grown in 24-well $\left(2 \mathrm{~cm}^{2}\right)$ tissue culture plates were treated with vehicle or Dex for designated time periods and concentrations. At the end of experimental periods, medium was removed and cells were incubated for 10 minutes at $37^{\circ} \mathrm{C}$ in calcium- and magnesium-free Hank's balanced salt solution (HBSS) containing $0.1 \%$ BSA and $1 \mathrm{mM}$ IBMX to inhibit phosphodiesterase activity. PDL cells were then stimulated with different agonists for an additional 10 minutes at $37^{\circ} \mathrm{C}$. The reaction was stopped by removing medium and adding ice-cold $5 \%$ perchloric acid $(250 \mu \mathrm{l})$ to each well. Plates were frozen at $-20^{\circ} \mathrm{C}$ for a minimum of 2 hours to extract the cAMP. After thawing, $\mathrm{pH}$ of the extracts was adjusted to 7.5 with $4 \mathrm{M} \mathrm{KOH}$, and centrifuged to remove the precipitate. The neutralized extract was then tested for cAMP content using a cAMP binding protein assay.

The cAMP binding protein assay was done as described previously [23] with minor modifications [24, 25], using bovine skeletal muscle as the source of binding protein. Assay buffer ( $50 \mathrm{mM}$ tris, 5 mM EDTA, 0.2\% BSA; pH 7.4), $100 \mu \mathrm{l}$ cAMP standards or unknowns, ${ }^{3}[\mathrm{H}] \mathrm{cAMP}(10,000 \mathrm{cpm} /$ tube $)$, and cAMP binding protein sufficient to bind $40-60 \%$ of the added radioactivity were added to each tube to a final volume of $250 \mu \mathrm{l}$. The tubes were incubated for 90 minutes at $4^{\circ} \mathrm{C}$. Dextran-coated charcoal $(0.5 \mathrm{mg} / \mathrm{ml}$ dextran and $5 \mathrm{mg} / \mathrm{ml}$ charcoal) was added to each tube $(600 \mu \mathrm{l})$, incubated for an additional 30 minutes at $4^{\circ} \mathrm{C}$, then centrifuged to remove unbound from bound cAMP-binding protein complexes. The supernatant was decanted directly into scintillation vials and counted in a liquid scintillation counter (Pharmacia, Wallac 1410). Samples were run in duplicate and concentration of CAMP was calculated by log-logit transformation (Securia 1.0, Packard, Downers Grove, IL). Data were expressed as pmol cAMP/10 7 cells.

\section{Data Analyses}

Data were analyzed by one-way analysis of variance with TukeyKramer multiple comparisons test, Dunnett multiple comparisons test, or unpaired Student's $t$ test (Instat 2.0, GraphPAD Software, San Diego, CA). All assays were performed two or three times and representative data are shown.

\section{Results}

Figure 1 indicates the dose-dependent effect of Dex on PTHstimulated cAMP production in PDL. Treatment of PDL cells with Dex (0-1000 nM) resulted in a dose-dependent increase in PTH-stimulated cAMP synthesis. This response was observed with PDL cell populations obtained from three different patients (Fig. $1 \mathrm{a}, \mathrm{b}, \mathrm{c}$ ). Dex (10-1000 nM) caused a significant increase in PTH (1-34)-stimulated cAMP production when compared with the basal levels of cAMP for each concentration (PTH-stimulated versus basal). Although Dex caused an increase in basal cAMP production, this increase was found statistically significant at the highest concentrations of Dex only, when compared with control (no Dex and no PTH). The ability of Dex to augment the cAMP response to PTH (1-34) was seen at a concentration as low as $10 \mathrm{nM}$.

To further characterize Dex's effect on PTH-stimulated cAMP response in PDL cells, several additional experiments were performed. Figure 2 represents the time course of cAMP response for PTH (1-34)-(100 nM) stimulated (Fig. 2a) and nonstimulated (Fig. 2b) PDL cells after treatment 1-14 days with Dex (0-1000 $\mathrm{nM})$. The statistically significant Dex effect was first apparent on day 7 when compared with day 1 (Table 1). As seen in Figure 2a, there was a progressive and significant augmentation of PTH (1-34) responsiveness of PDL cells with increased duration of Dex treatment. The dramatic increase in PTH (1-34)-mediated cAMP synthesis with $100 \mathrm{nM}$ Dex on day 14 was found repeatedly, in two different experiments, with cells from different donors. There was no statistically significant difference in cell number between control and Dex-treated cultures after 14 days of treatment (data not shown). Dex treatment alone (no PTH) did not cause any difference in cAMP production in PDL cells for the time periods examined (Fig. 2b). 

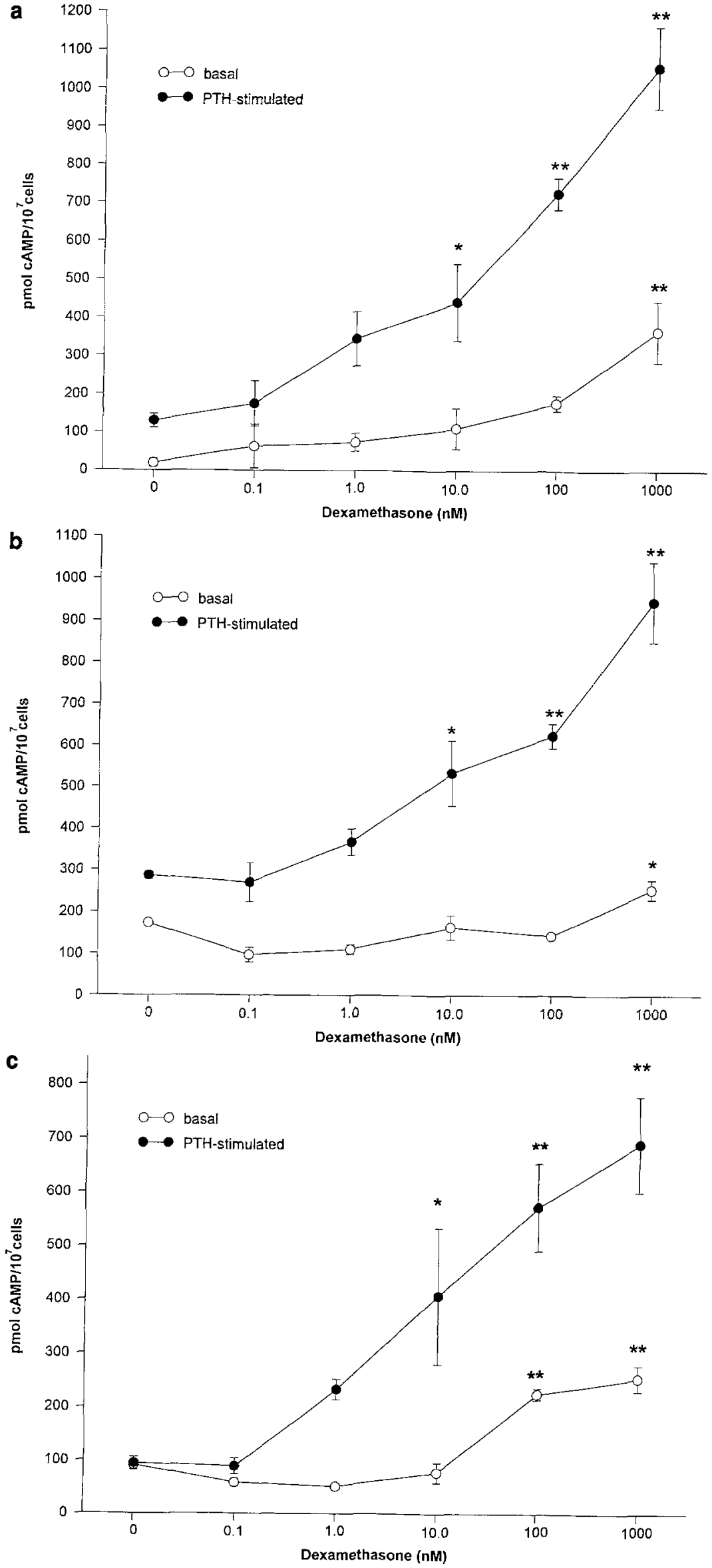

Fig. 1. The effects of varying concentrations of Dex on PTH-stimulated cAMP production in PDL cells obtained from three different patients $(a, b, c)$. PDL cells were incubated with different concentrations of Dex (0-1000 $\mathrm{nM}$ ) for 7 days. PTH (1-34) (100 nM)stimulated and basal (nonstimulated) cAMP levels were estimated in the cultures as described in Materials and Methods. Values are expressed as the mean \pm SEM from triplicate wells. Statistical comparison was applied to separate groups with each concentration compared to control (no Dex) using the Dunnett multiple comparison test. ${ }^{*} P<0.05 ;{ }^{* *} P<0.01$. 
a

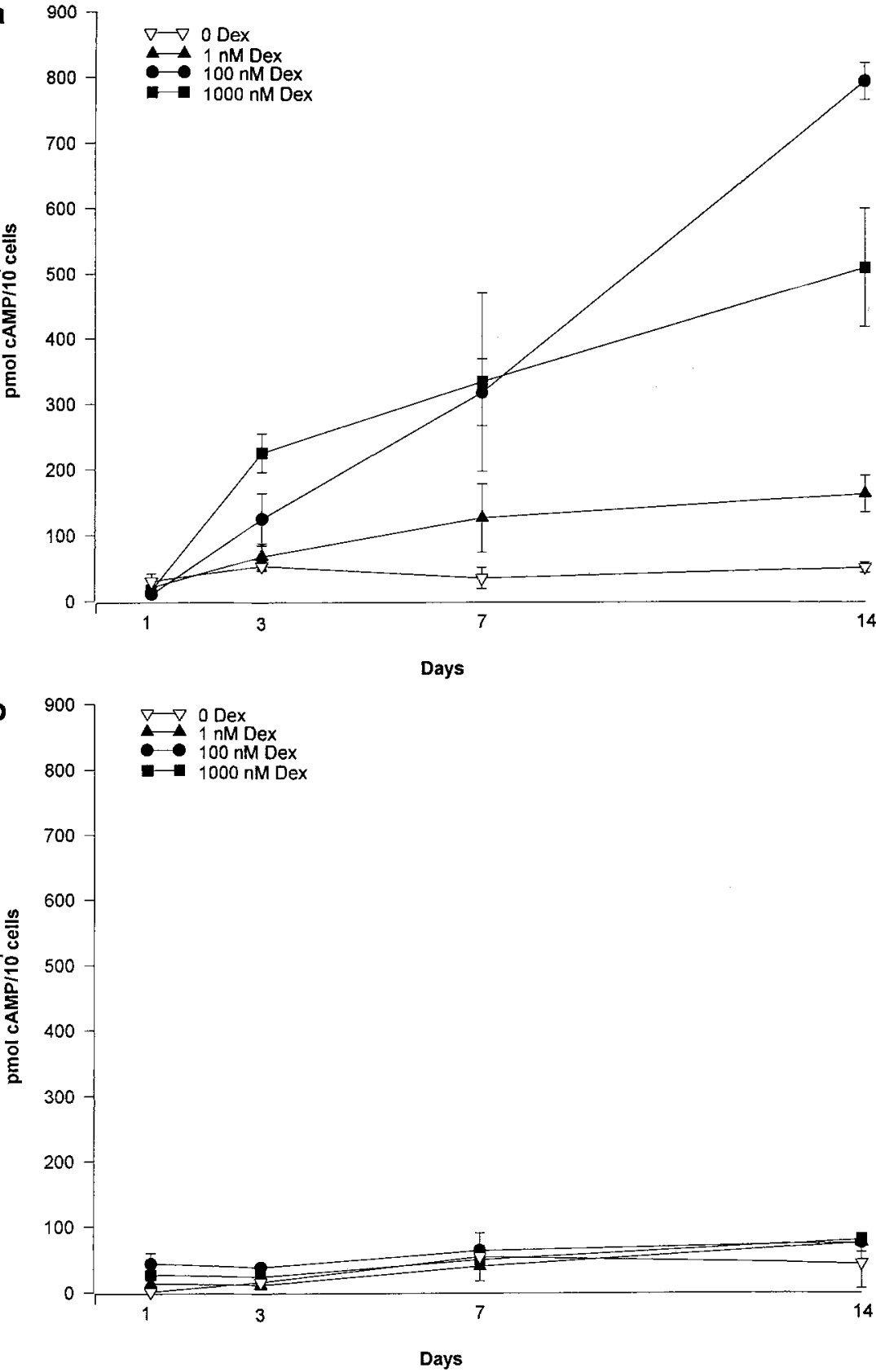

Fig. 2. Time course effects of Dex on cAMP response of PTH (1-34)-stimulated (a) and nonstimulated (b) periodontal ligament cells. Cells were treated with Dex $(0-1000 \mathrm{nM})$ for periods of $1,3,7$, and 14 days. At the end of each time period PDL cells were stimulated with PTH (1-34) (100 nM) and cell extracts were frozen until cAMP determination. The statistical analyses (Tukey-Kramer multiple comparison test) for Figure 2 (a) are shown in Table 2. No difference at any time point was observed in CAMP levels for Dex-treated non-PTH (1-34)-stimulated PDL cells with time of treatment (b). Data represent the mean of triplicate samples \pm SEM. (For statistical analysis see Table 1.)

Table 1. Statistical analysis for Figure 2a

\begin{tabular}{|c|c|c|}
\hline $\operatorname{Dex}(\mathrm{nM})$ & Significance & \\
\hline 0 & \multicolumn{2}{|l|}{ No significant difference between the days } \\
\hline 1 & No significant difference between the days & \multirow{4}{*}{ Day 7 vs day $14^{\mathrm{c}}$} \\
\hline 100 & Day 1 vs day $7^{\mathrm{b}} \quad$ Day 3 vs day $7^{\mathrm{a}}$ & \\
\hline & Day 1 vs day $14^{\mathrm{c}}$ & \\
\hline 1000 & Day 1 vs day $14^{\mathrm{a}}$ & \\
\hline
\end{tabular}

The dose-response effect of PTH (1-34) on stimulation of cAMP in Dex-treated PDL cells is shown in Figure 3. Dexamethasone treatment increased the sensitivity of PDL cells to PTH (1-34) and this response was PTH (1-34) dose dependent. PTH (1-34)-stimulated cAMP activity was increased in
Dex-treated PDL cells at concentrations of 1-1000 nM. Furthermore, there was no significant or dose-dependent augmentation of cAMP production in PDL cells nonstimulated or stimulated with PTH (7-34), a PTH antagonist, after Dex treatment. 


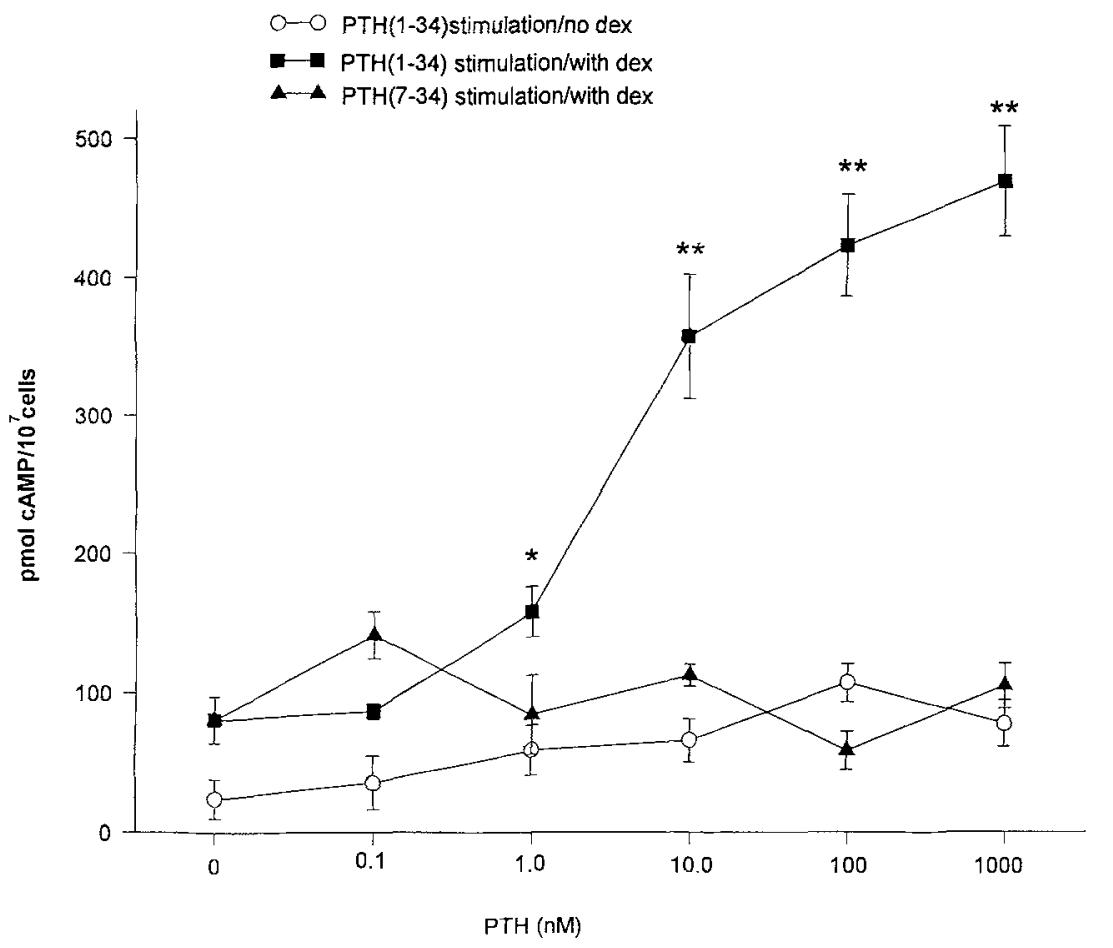

Fig. 3. Dexamethasone potentiation of cAMP response in periodontal ligament cells stimulated by PTH (1-34) and PTH (7-34). Cells were treated with Dex $(1000 \mathrm{nM})$ or vehicle for 7 days and stimulated with varying concentrations (0-1000 nM) of PTH (1-34) or PTH (7-34) for 10 minutes. The concentration of cAMP in the cell extracts was determined by cAMP protein assay. Tukey-Kramer muitiple comparisons test was applied for statistical analyses. Each point represents the mean of triplicate samples \pm SEM. ${ }^{*} P<$ $0.05{ }^{* *} P<0.001$ when compared with control (Dex,+ PTH -$)$.
Table 2. The effect of Dex on calcitonin-, isoproterenol-, forskolin-, and PTH(1-34)-stimulated cAMP production in periodontal ligament cells

cAMP pmol $/ 10^{7}$ cells

\begin{tabular}{lrrrr}
\hline & \multicolumn{1}{c}{ Dex } & \multicolumn{1}{c}{+ Dex } \\
\hline Control & $40.46 \pm 2.91$ & $48.31 \pm$ & 5.93 \\
Calcitonin & $53.93 \pm 6.00$ & $74.76 \pm 15.86$ \\
Forskolin & $4653.91 \pm 1.70$ & $4135.30 \pm 848.05$ \\
Isoproterenol & $2379.17 \pm 93.09$ & $2537.16 \pm 92.39$ \\
PTH(1-34) & $154.92 \pm 13.90$ & $562.25 \pm$ & $4.21^{*}$
\end{tabular}

*P<0.0001 when compared with non-Dex-treated cultures. Cells were cultured in the presence of $\operatorname{Dex}(1000 \mathrm{nM})$ for 7 days, and stimulated with calcitonin $(1 \mu \mathrm{M})$, isoproterenol $(1 \mu \mathrm{M})$, forskolin (1 $\mu \mathrm{M})$, and PTH(1-34) (100 nM) for 10 minutes. Unpaired Student's $t$ test was performed for statistical comparisons. Results represent mean \pm SEM of triplicate determinations from one of two similar experiments.

Forskolin and isoproterenol have been shown to be potent stimulators of adenylate cyclase. As shown in Table 2, forskolin and isoproterenol caused a substantial increase in cAMP production following 10 minutes of stimulation. However, neither forskolin nor isoproterenol stimulation were enhanced by Dex treatment. Furthermore, Dex did not alter calcitonin effects on cAMP in PDL cells.

\section{Discussion}

The results of the studies presented here establish that dexamethasone promotes PTH (1-34)-stimulated cAMP synthesis in PDL cells. This result adds important information with regard to characteristics of PDL cells. Glucocorticoids have been reported to augment the cAMP response to PTH stimulation in osteoblastic cells from different species in vitro, and thus the findings of the present study support past studies indicating osteoblast-like characteristics of periodontal ligament cells. PDL contains a heterogenous cell population [26], with some cells having more osteoblastic properties including high alkaline phosphatase levels, PTH-mediated cAMP synthesis, ability to form mineral-like nodules, and $1,25(\mathrm{OH})_{2} \mathrm{D}_{3}$-stimulated bone Gla protein synthesis [4, 5, 13]. Glucocorticoid enhancement of PTH (1-34)-stimulated cAMP production in PDL cells is a new example of the presence and induction of an osteoblast-like population within the PDL.

Dex's ability to enhance PTH (1-34)-mediated cAMP response of PDL cells was extremely reproducible and observed repeatedly in numerous experiments with PDL cells obtained from different donors (Fig. 1). Furthermore, differences in magnitude of cAMP production measured with the cells from different donors supports the presence of heterogenous cell populations within the PDL.

Exposure of PDL cells to Dex for 1 day did not cause any significant increase in PTH (1-34)-stimulated cAMP production (Fig. 2). The earliest time period that Dex caused a significant increase in PTH-stimulated cAMP when compared to day 1 was day 7 . Using ROS $17 / 2.8$ cells, it has been reported that the earliest effect of glucocorticoid treatment on enhancing adenylate cyclase was 12 hours $[22,27,28]$. The difference between these findings and our results may be explained by the heterogeneous nature of cultured PDL cells, where only a few cells have osteoblastic characteristics. Another possibility is a difference in the number of receptors for both Dex and PTH in ROS $17 / 2.8$ versus PDL cells. Although cAMP synthesis in response to PTH was dose dependent on days 3 and 7 , a biphasic effect was observed on day 14. The PTH-mediated cAMP response by PDL cells was higher in cells exposed to $100 \mathrm{nM}$ Dex than cells exposed to $1000 \mathrm{nM}$ Dex. The reason for this is not clear, but a biphasic PTH-stimulated cAMP dose response curve has been observed previously in human trabecular explant cultures after treatment with Dex [20]. 
Human PDL cells responded to PTH (1-34) fragment stimulation with a dose-dependent increase in CAMP production after Dex treatment for 7 days (Fig. 3). However, stimulation of the cells with a PTH analog, PTH (7-34), did not cause any augmentation of cAMP production following Dex treatment. The portion of the PTH molecule necessary for adenylate cyclase stimulation resides in the first three amino acids of PTH. These data suggest that the Dex effect is dependent on PTH (1-34)-stimulated cAMP synthesis in human periodontal ligament cells.

To further characterize the mechanism of cAMP augmentation caused by Dex treatment and to establish the specificity of the stimulatory effect of Dex on cAMP production, different agents known to stimulate intracellular cAMP synthesis (i.e., forskolin and isoproterenol and as a control, calcitonin) were also used. Glucocorticoid effects on components of cAMP activation have been reported for other cell systems [29-31]. It has been shown that Dex stimulates PTH-responsive adenylate cyclase in ROS $17 / 2.8$ cells by increasing either $G_{s}$ subunits [32] or activity of the catalytic unit [33]. Forskolin, a diterpene, is a well-known cAMP stimulator and has been shown to activate adenylate cyclase, directly stimulating the catalytic unit in intact cells [34]. In the present study, forskolin stimulated cAMP production was unaltered by Dex treatment in PDL cells. In contrast, forskolin stimulation of cAMP synthesis was enhanced by Dex in $\operatorname{ROS} 17 / 2.8[28,32]$ and in human bone-derived cells [20]. Isoproterenol, another activator of adenylate cyclase which acts via a separate receptor, was also evaluated. Although isoproterenol did stimulate cAMP synthesis in PDL cells, the isoproterenol effect was not potentiated by Dex treatment. Studies with other cell populations showed an enhanced cAMP stimulation by isoproterenol after Dex treatment $[20,22,28,29]$. Calcitonin was used as a negative control as we previously reported that it has no effect on cAMP synthesis in PDL cells [6]. In the present study there was no alteration in cAMP levels in Dex-treated PDL cells. This is in agreement with Chen and Feldman [19] who reported Dex potentiation of cAMP production after PTH stimulation but not calcitonin stimulation in cultured rat bone cells.

The unaltered stimulation of cAMP in response to forskolin, isoproterenol, and calcitonin by Dex treatment suggests that the stimulatory effect of Dex is specific to PTH and is a PTH receptor-mediated event. These findings support other studies examining the interaction between Dex and PTH receptors in osteoblast cells. When ROS 17/2.8 cells were treated with glucocorticoids, an increase in the availability of receptor binding sites, but not altered receptor binding affinity, was found $[28,35]$. A recent study by Urena et al. [36] reported that Dex dramatically increased PTH/ PTHrP receptor mRNA expression in the ROS 17/2.8 cells.

The results from the present study confirm that PDL in vitro contains cells with osteoblast-like characteristics. Furthermore, Dex enhances PTH responsiveness of these cells by increasing cAMP synthesis after hormone stimulation. Interestingly, Rutherford et al. [37] reported that Dex acts synergistically with platelet-derived growth factor (PDGF) to enhance mitogenic effects of PDGF on fibroblasts obtained from human PDL and gingival tissue. In a recent study, they also observed an increase in periodontal regeneration with new cementum, ligament, and supra-crestal bone formation in periodontal lesions in monkeys treated with PDGF-Dex-collagen matrix combination [38]. These effects of Dex may partly be related to the ability of Dex to trigger cell differentiation in a selected group of cells. Further investigations directed at the mechanism of Dex effects on PDL cells, and synergy between Dex and growth factors may provide a better understanding of the role these cells play in the maintenance and regeneration of the PDL and remodeling of the adjacent bone and cementum.

Acknowledgments. The authors express their appreciation to Dr. Thomas J. Rosol for supplying cAMP binding protein. This research was supported by grant \# DE09532 and \# DK46919 from the NIH, and ECZACIBASI (Procter and Gamble, Istanbul, Turkey), and Procter and Gamble, Cinncinati, OH, USA.

\section{References}

1. Nyman S, Lindhe J, Karring T, Rylander H (1982) New attachment following surgical treatment of human periodontal disease. J Clin Periodontol 9:290-296

2. Egelberg J (1987) Regeneration and repair of periodontal tissues. J Periodont Res 22:233-242

3. Aukhil I, Nishimura K, Fernyhough W (1990) Experimental regeneration of the periodontium. Crit Rev Oral Biol Med 1:101105

4. Nojima N, Kobayashi M, Shionome M, Takahashi N, Suda T, Hasegawa K (1990) Fibroblastic cells derived from bovine periodontal ligaments have the phenotypes of osteoblasts. J Periodont Res 25:179-185

5. Somerman MJ, Young MF, Foster RA, Moehring JM, Imm G, Sauk JJ (1990) Characteristics of human periodontal ligament cells in vitro. Arch Oral Biol 35:241-247

6. Nohutcu RM, McCauley LK, Horton JE, Capen CC, Rosol TJ (1993) Effects of hormones and cytokines on stimulation of adenylate cyclase and intracellular calcium concentration in human and canine periodontal-ligament fibroblasts. Arch Oral Biol 38:871-879

7. Matsuda N, Lin WL, Kumar NM, Cho MI, Genco RJ (1992) Mitogenic, chemotactic, and synthetic responses of rat periodontal ligament fibroblastic cells to polypeptide growth factors in vitro. J Periodontol 63:515-525

8. Somerman MJ, Foster RA, Imm GM, Sauk JJ, Archer SY (1989) Periodontal ligament cells and gingival fibroblasts respond differently to attachment factors in vitro. J Periodontol 60:73-77

9. Somerman MJ, Foster RA, Sauk JJ (1992) Biochemical analysis of periodontal cell activities. In: Davidovitch Z (ed) Biological mechanism of tooth movement and craniofacial adaptation. EBSCO Media, Birmingham AL, pp 291-300

10. Isidor F, Karring T, Nyman S, Lindhe J (1986) The significance of coronal growth of periodontal ligament tissue for new attachment formation. J Clin Periodont 13:145-150

11. Somerman MJ, Archer SY, Imm GR, Foster RA (1988) A comparative study of human periodontal ligament cells and gingival fibroblasts in vitro. J Dent Res 67:66-70

12. Piche JE, Carnes DL, Graves DT (1989) Initial characterization of cells derived from human periodontia. J Dent Res 68:761-767

13. Arceo N, Sauk JJ, Moehring J, Foster RA, Somerman MJ (1991) Human periodontal cells initiate mineral-like nodules in vitro. $J$ Periodontol 62:499-503

14. Salhanick AI, Krupp MN, Amatruda JM (1983) Dexamethasone stimulates insulin receptor synthesis in cultured rat hepatocytes. J Biol Chem 258:14130-14135

15. Ivanovic V, Weinstein IB (1981) Glucocorticoids and benzo(a)pyrene have opposing effects on EGF receptor binding. Nature 293:404-406

16. Bellows CG, Heersche JNM, Aubin JE (1990) Determination of the capacity for proliferation and differentiation of osteoprogenitor cells in the presence and absence of dexamethasone. Dev Biol 140:132-138

17. Kasugai S, Todescan R, Nagata T, Yao K-L, Butler WT, Sodek $J$ (1991) Expression of bone matrix proteins associated with mineralized tissue formation by adult rat bone marrow cells in vitro: inductive effects of dexamethasone on the osteoblastic phenotype. J Cell Physiol 147:111-120 
18. Cheng S-L, Yang JW, Rifas L, Zhang S-F, Avioli LV (1994) Differentiation of human bone marrow osteogenic stromal cells in vitro: induction of the osteoblast phenotype by dexamethasone. Endocrinology 134:277-286

19. Chen TL, Feldman D (1979) Glucocorticoid receptors and actions in subpopulations of cultured bone cells: mechanisms of dexamethasone potentiation of parathyroid hormone-stimulated cyclic AMP production. J Clin Invest 63:750-758

20. Wong M-M, Rao LG, Ly H, Hamilton L, Tong J, Sturtridge W, McBroom R, Aubin JE, Murray TM (1990) Long-term effects of physiological concentrations of dexamethasone on human bonederived cells. J Bone Miner Res 5:803-813

21. Durant S, Duval D, Homo-Delarche F (1986) Factors involved in the control of fibroblast proliferation by glucocorticoids: a review. Endocr Rev 7:254-269

22. Rodan SB, Fisher MK, Egan JJ, Epstein PM, Rodan GA (1984) The effect of dexamethasone on parathyroid hormone stimulation of adenylate cyclase in ROS 17/2.8 cells. Endocrinology 115:951-958

23. Shanfeld J, Davidovitch Z (1981) Simultaneous extraction and assay of cyclic nucleotides, prostaglandins, and DNA from cat alveolar bone. Anal Biochem 113:256-263

24. McCauley LK, Beecher CA, Melton ME, Werkmeister JR, Jüppner H, Abou-Samra A, Segre GV, Rosol TJ (1994) Transforming growth factor- $\beta_{1}$ regulates steady state PTH/PTHrP receptor mRNA levels and PTHrP binding in ROS 17/2.8 osteosarcoma cells. Mol Cell Endocrinol 101:331-336

25. McCauley LK, Rosol TJ, Merryman JI, Capen CC (1992) Parathyroid hormone-related protein binding to human T-cell lymphotropic virus type I-infected lymphocytes. Endocrinology $130: 300-306$

26. McCulloch CAG, Bordin S (1991) Role of fibroblast subpopulations in peridontal physiology and pathology. J Periodont Res 26:144-154

27. Catherwood BD (1985) 1,25-Dihydroxycholecalciferol and glucocorticosteroid regulation of adenylate cyclase in an osteoblast-like cell line. J Biol Chem 260:736-743

28. Yamamoto I, Potts JT, Segre GV (1988) Glucocorticoids increase parathyroid hormone receptors in rat osteoblastic osteosarcoma cells (ROS 17/2). J Bone Miner Res 3:707-712
29. Johnson GS, Jaworski CJ (1983) Glucocorticoids increase GTPdependent adenylate cyclase activity in cultured fibroblasts. Mol Pharmacol 23:648-652

30. Rao LG, Wylie JN (1993) Modulation of parathyroid hormonesensitive adenylate cyclase in ROS $17 / 2.8$ cells by dexamethasone, 1,25-dihydroxyvitamin $\mathrm{D}_{3}$ and protein kinase $\mathrm{C}$. Bone Miner 23:35-47

31. Zajac JD, Livesey SA, Michelangeli VP, Rodan SB, Rodan GA, Martin TJ (1986) Glucocorticoid treatment facilitates cyclic adenosine $3^{\prime}, 5^{\prime}$-monophosphate-dependent protein kinase response in parathyroid hormone-responsive osteogenic sarcoma cells. Endocrinology 188:2059-2064

32. Rodan SB, Rodan GA (1986) Dexamethasone effects on $\beta$-adrenergic receptors and adenylate cyclase regulatory proteins $\mathrm{G}_{\mathrm{S}}$ and $G_{I}$ in ROS 17/2.8 cells. Endocrinology 118:2510-2518

33. Rizzoli R, von Tscharner V, Fleisch $H$ (1986) Increase of adenylate cyclase catalytic-unit activity by dexamethasone in rat osteoblast-like cells. Biochem J 237:447-454

34. Darfler FJ, Mahan LC, Koachman AM, Insel PA (1982) Stimulation by forskolin of intact $\mathbf{S} 49$ lymphoma cells involves the nucleotide regulatory protein of adenylate cyclase. J Biol Chem 257:11901-11905

35. Titus L, Jackson E, Nanes MS, Rubin JE, Catherwood BD (1991) 1,25-Dihydroxyvitamin D reduces parathyroid hormone receptor number in ROS $17 / 2.8$ cells and prevents the glucocorticoid-induced increase in these receptors: relationship to adenylate cyclase activation. I Bone Miner Res 6:631 -637

36. Urena $P$, Ilda-Klein A, Kong X-F, Jüppner H, Kronenberg HM, Abou-Samra A, Segre GV (1994) Regulation of parathyroid hormone (PTH)/PTH-related peptide receptor messenger ribonucleic acid by glucocorticoids and PTH in ROS 17/2.8 and OK cells. Endocrinology 134:451-456

37. Rutherford RB, TrailSmith MD, Ryan ME, Charette MF (1992) Synergistic effects of dexamethasone on platelet-derived growth factor mitogenesis in vitro. Arch Oral Biol 37:139-145

38. Rutherford RB, Ryan ME, Kennedy JE, Tucker MM, Charette MF (1993) Platelet-derived growth factor and dexamethasone combined with a collagen matrix induce regeneration of the periodontium in monkeys. J Clin Periodontol 20:537-544 